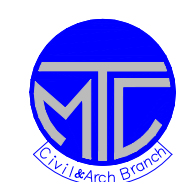

ICCAE

Military Technical College

Kobry Elkobbah, Cairo, Egypt $7^{\text {th }}$ International Conference

On Civil \& Architecture

Engineering

\title{
WATER PERMEABILITY AND STRENGTH OF CONCRETE CONTAINING SILICA FUME, FLY ASH, SUPER POZZ, AND HIGH SLAG CEMENT
}
A.A.Saker*
E.M.Eltehewy ${ }^{* *}$
A.A.Elsayed ${ }^{* \star *}$
Y.B.I.Shaheen ${ }^{* \star * *}$

\begin{abstract}
In this study, effects of mineral admixtures on the water permeability and compressive strength of concretes containing silica fume (SF) and fly ash (FA), super pozz (SP) were experimentally investigated. Permeability of concrete was determined through DIN 1048 (Part 5). The research variables included cement type, ordinary Portland cement (OPC) or high slag cement (HSC), and mineral admixtures content were used as a partial cement replacement. They were incorporated into concrete at the levels of $5 \%, 10 \%$, and $15 \%$ for silica fume and $10 \%, 20 \%, 30 \%$ for fly ash, or super pozz by weight of cement. Water- cement ratio of 0.40 was used and tests were carried out at 28 days. From the tests, the lowest measured water permeability was for the $10 \%$ super pozz and $10 \%$ silica fume or $20 \%$ fly ash mixes. Although the highest compressive strengths of concretes determined was $10 \%$ silica fume mix for ordinary Portland cement and were reduced as the increase in the replacement ratios for other mineral admixtures than ordinary Portland cement concrete. The main objective of this research was to study the water permeability and compressive strength of concrete containing silica fume, fly ash, and super pozz and high slag cement to achieve the best concrete mixture have lowest permeability.

The results were compared to the control concrete ordinary Portland cement concrete without admixtures. The optimum cement replacement by FA, SP and SF in this experiment is $10 \% \mathrm{SP}$.

The knowledge on the strength and permeability of concrete containing silica fume and fly ash, super pozz and high slag cement could be beneficial on the utilization of these waste materials in concrete work, especially on the topic of durability.
\end{abstract}

Keywords: Permeability, Silica fume (SF), Fly ash (FA), Super pozz (SP), high slag cement (HSC).

\footnotetext{
*Col. Eng. Syrian

${ }^{* *}$ Col. Dr. Military Technical Collage.

${ }^{* * *}$ Mag.Gen .Ass .prof. Dr. Military Technical Collage.

${ }^{* * * *}$ Prof. Dr. Faculty of Engineering Elmenofia University.
} 


\section{INTRODUCTION}

It is known that the permeability controls deterioration of concrete in aggressive environment [1, 2], because the processes of such deterioration as carbonation, chloride attack and sulfates attack are governed by the fluid transportation in concrete. fillers and pozzolanic materials are introduced to improve the strength and other properties of concrete for necessary conditions.

Fly ash and Super pozz are produced from burning of powdered coal in power plants. Silica fume is also known as micro silica, volatilized silica, or condensed silica fume. It is a by-product from silicon metal and ferrosilicon alloy production. The material is a very fine powder with spherical particles about 100 times smaller in size than Portland cement or fly ash.

Slag is a by-product from the production of steel. During production liquid slag is rapidly quenched from a high temperature by immersion in water [3]. The slag is a glassy, granular, non-metallic product that consists "essentially of silicates and aluminosilicates of calcium and other bases" [4]. It is also known as granulated blast furnace slag (GBFS).

The aim of this research was to study the water permeability and compressive strength of concrete containing silica fume and fly ash; super pozz and high slag cement to achieve the best concrete mixture having lowest permeability. The results were compared to the control concrete ordinary Portland cement concrete without admixtures.

The knowledge on the strength and permeability of concrete containing silica fume and fly ash, super pozz and high slag cement could be beneficial on the utilization of these waste materials in concrete work, especially on the topic of durability.

\section{EXPERIMENTAL PROGRAM}

\subsection{Materials}

\subsubsection{Cement and Cement replacement materials}

\subsubsection{Ordinary Portland cement}

Ordinary Portland cement used was provided from Tourah-factory. The approximate mineral composition of the used cement is shown in Table (1) [6].

Table (1) Typical Composition of Ordinary Portland Cement

\begin{tabular}{|c|c|c|c|c|c|c|}
\hline constituents & $\mathrm{C}_{3} \mathrm{~S}$ & $\mathrm{C}_{2} \mathrm{~S}$ & $\mathrm{C}_{3} \mathrm{~A}$ & $\mathrm{C}_{4} \mathrm{AF}$ & $\mathrm{CSH}_{2}$ & Total \\
\hline Percent \% & 50 & 25 & 12 & 8 & 3.5 & 98.5 \\
\hline
\end{tabular}

\subsubsection{High slag cement}

Slag is a by-product from the production of steel. During production liquid slag is rapidly quenched from a high temperature by immersion in water [3]. The slag is a glassy, granular, non-metallic product that consists "essentially of calcium silicates 
and calcium aluminosilicates and other bases" [4]. It is also known as granulated blast furnace slag (GBFS). Slag, in addition to pozzolanic properties, and unlike Class $\mathrm{F}$ fly ash and silica fume, also has cementitious properties. With regard to strength, there are three grades of slag: Grade 80, Grade 100, and Grade 120. Each number corresponds to a minimum 28-day compressive strength ratio of a mortar cube made with only Portland cement and a mortar cube made with $50 \%$ Portland cement and $50 \%$ slag. Because of cementitious properties, particles smaller than 10 $\mu \mathrm{m}$ contribute to early strength, while particles larger than $10 \mu \mathrm{m}$ and smaller than 45 $\mu \mathrm{m}$ contribute to later strength. Since particles greater than $45 \mu \mathrm{m}$ are difficult to hydrate, slag is mostly pulverized to particles with diameter less than $45 \mu \mathrm{m}$ [3].

When used in concrete, slag provides the following benefits [9]:

- High ultimate strength with low early strength,

- High ratio of flexural to compressive strength,

- Resistant to sulfates and seawater,

- Improved alkali-silica reaction resistance,

- Low heat of hydration,

- Decreased porosity and permeability, and

- Better finish and lighter color.

Slag is also known for improved workability and lower water requirement [10]. Slag hydration is significantly influenced by temperature: hydration is accelerated at higher temperatures and retarded at lower ones, when compared to Portland cement hydration. This may lead to differences between the strength of concrete in the field and the laboratory specimens [3]. The chemical analysis and physical properties of slag in Table (2) [5].

Table (2) Chemical Analysis and Physical Properties of Slag

\begin{tabular}{|l|c|}
\hline \multicolumn{1}{|c|}{ Analysis and properties } & Mass \% \\
\hline $\mathrm{SiO}_{2}$ & 39.0 \\
\hline $\mathrm{Al}_{2} \mathrm{O}_{3}$ & 8.7 \\
\hline $\mathrm{Fe}_{2} \mathrm{O}_{3}$ & 0.5 \\
\hline $\mathrm{CaO}$ & 41.3 \\
\hline $\mathrm{MgO}$ & 8.5 \\
\hline $\mathrm{Na}_{2} \mathrm{O}$ & 0.15 \\
\hline $\mathrm{K}_{2} \mathrm{O}$ & 0.21 \\
\hline $\mathrm{SO}_{3}$ & 0.74 \\
\hline Loss on ignition (LOI) & 0.52 \\
\hline Specific Surface Area $\left(\mathrm{cm}^{2} / \mathrm{g}\right)$ & 7000 \\
\hline Specific gravity & 2.92 \\
\hline
\end{tabular}




\subsubsection{Fly ash}

Fly ashes are by-products manufactured during combustion of powdered coal in power plants. A summary of the properties and chemical composition of different fly ashes was presented by Helmuth [6]. In general, depending on the chemical composition, fly ash can be classified as Class F or Class C. Class C fly ash has higher amount of $\mathrm{CaO}$ so it possesses more cementing characteristics and is less pozzolanic than Class F. ASTM 618 states that Class F fly ash is "normally produced from burning anthracite or bituminous coal", while Class C fly ash is "normally produced from lignite and subbituminous coal" [8]. Class F fly ash is mostly composed of silicate glass containing aluminum, iron, and alkalies. The particles are in the form of solid spheres with sizes ranging from less than $1 \mu \mathrm{m}$ to $100 \mu \mathrm{m}$, and an average diameter of $20 \mu \mathrm{m}$ [3]. At least $70 \%$ of the chemical composition is made up of $\mathrm{SiO}_{2}, \mathrm{Al}_{2} \mathrm{O}_{3}$, and $\mathrm{Fe}_{2} \mathrm{O}_{3}$ [4]. The chemical analysis and physical properties of fly ash shown in Table (3).

The benefits for using fly ash in concrete include the following [4]:

- Improved workability,

- Lower heat of hydration,

- Lower cost concrete,

- Improved resistance to sulfate attack,

- Improved resistance to alkali-silica reaction,

- Higher long-term strength,

- Opportunity for higher strength concrete,

- Equal or increased freeze thaw durability,

- Lower shrinkage characteristics, and

- Lower porosity and improved impermeability.

Table (3) Chemical Analysis and Physical Properties of Fly Ash

\begin{tabular}{|l|c|}
\hline \multicolumn{1}{|c|}{ Chemical Analysis Mass \% } & Mass \% \\
\hline Silica $\left(\mathrm{SiO}_{2}\right)$ & $47.0-55.0$ \\
\hline Aluminium $\left(\mathrm{Al}_{2} \mathrm{O}_{3}\right)$ & $25.0-35.0$ \\
\hline Iron $\left(\mathrm{Fe}_{2} \mathrm{O}_{3}\right)$ & $3.0-4.0$ \\
\hline Manganese $\left(\mathrm{Mn}_{2} \mathrm{O}_{3}\right)$ & $0.1-0.2$ \\
\hline Calcium $(\mathrm{CaO})$ & $4.0-10.0$ \\
\hline Magnesium $(\mathrm{MgO})$ & $1.0-2.5$ \\
\hline Phosphorus $\left(\mathrm{P}_{2} \mathrm{O}_{5}\right)$ & $0.5-1.0$ \\
\hline Potassium $\left(\mathrm{K}_{2} \mathrm{O}\right)$ & $0.5-1.0$ \\
\hline Sodium $\left(\mathrm{Na}_{2} \mathrm{O}\right)$ & $0.2-0.8$ \\
\hline Titanium $\left(\mathrm{TiO}_{2}\right)$ & $1.0-0.5$ \\
\hline Sulphur $\left(\mathrm{SO}_{3}\right)$ & $0.1-0.5$ \\
\hline Loss On Ignition $(\mathrm{LOI})$ & $0.5-2.0$ \\
\hline Specific Surface Area(cm $\left.{ }^{2} / \mathrm{g}\right)$ & 8500 \\
\hline Specific gravity & 2.6 \\
\hline
\end{tabular}




\subsubsection{Super pozz}

As can be seen in the chemical composition and physical characteristics listed in Table 4, Super-Pozz is an extremely fine, light colored powder composed primarily of amorphous calcium-silicates and aluminates. From its chemical analysis, Super-Pozz will meet the Class F fly ash requirement of BS 3892, but physically the product is unique with regards to its particle size distribution. The D99 value is 25 micron, the particle size below which $99 \%$ of the particles are to be found. Figure 1, illustrates the comparative particle size distribution analysis. The chemical analysis and physical properties of super pozz shown in Table (4)

Table 4. Chemical Analysis and Physical Properties of Super Pozz

\begin{tabular}{|l|c|}
\hline \multicolumn{1}{|c|}{ Chemical Analysis Mass \% } & Mass \% \\
\hline $\mathrm{SiO}_{2}$ & 53.5 \\
\hline $\mathrm{Al}_{2} \mathrm{O}_{3}$ & 34.3 \\
\hline $\mathrm{CaO}$ & 4.4 \\
\hline $\mathrm{Fe}_{2} \mathrm{O}_{3}$ & 3.6 \\
\hline $\mathrm{K}_{2} \mathrm{O}$ & 0.8 \\
\hline $\mathrm{MgO}$ & 1.0 \\
\hline Loss On Ignition (LOI) & $<1.0$ \\
\hline Specific Surface Area $\left(\mathrm{cm}^{2} / \mathrm{g}\right)$ & 13000 \\
\hline Specific gravity & 2.20 \\
\hline
\end{tabular}

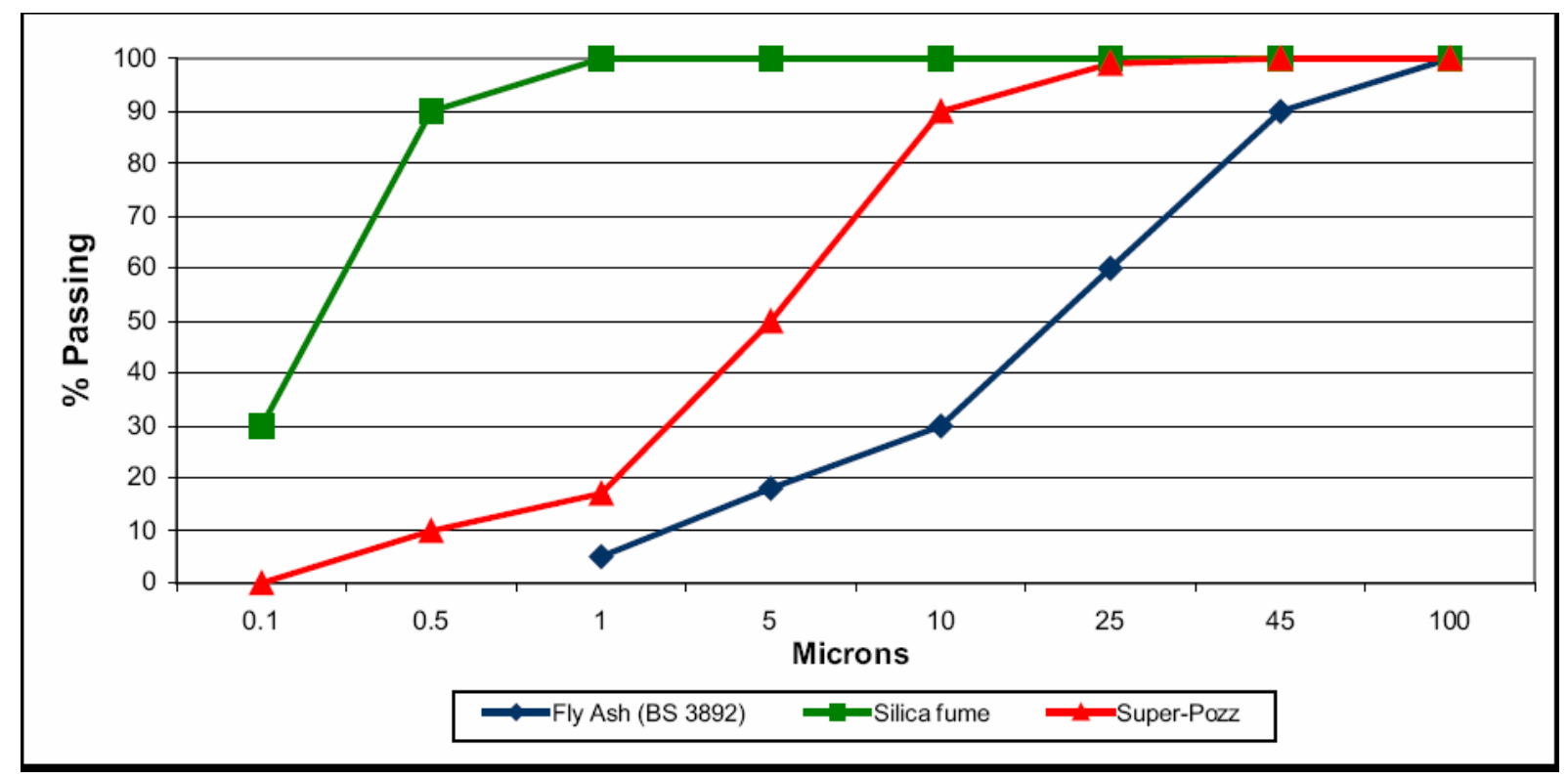

Figure 1: Particle Size Distribution 


\subsubsection{Silica fume}

Silica fume is also known as micro silica, volatilized silica, or condensed silica fume. It is a by-product from silicon metal and ferrosilicon alloy production. The material is a very fine powder with spherical particles about 100 times smaller in size than Portland cement or fly ash. The diameters range from 0.02 to $0.5 \mu \mathrm{m}$ with an average of $0.1 \mu \mathrm{m}$. Silica fume contains 85 to $95 \%$ noncrystalline silicon dioxide.

The first application of silica fume in the United States was conducted in Kentucky in 1982 [4]. The use of silica fume will make concrete with the following properties [5]:

- Low heat of hydration,

- Retarded alkali-aggregate reaction,

- Reduced freeze-thaw damage and water erosion,

- High strength,

- Increased sulfate resistance,

- Reduced permeability.

Silica fume is also known for creating problems in handling and cracking related to its small particle sizes and increased water requirement.

The chemical analysis and physical properties of Silica fume shown in Table (5).

Table (5) Chemical Analysis and Physical Properties of the Silica Fume

\begin{tabular}{|l|c|}
\hline \multicolumn{1}{|c|}{ Analysis and properties } & Mass \% \\
\hline $\mathrm{SiO}_{2}$ & 90.2 \\
\hline $\mathrm{Al}_{2} \mathrm{O}_{3}$ & 1.7 \\
\hline $\mathrm{Fe}_{2} \mathrm{O}_{3}$ & 0.4 \\
\hline $\mathrm{CaO}$ & 2.1 \\
\hline $\mathrm{MgO}$ & 1.7 \\
\hline $\mathrm{Na}_{2} \mathrm{O}$ & 0.7 \\
\hline $\mathrm{K}_{2} \mathrm{O}$ & 0.7 \\
\hline $\mathrm{SO}$ & \\
\hline Loss on ignition (LOI) & 0.5 \\
\hline Specific Surface Area $\left(\mathrm{cm}^{2} / \mathrm{g}\right)$ & 2.5 \\
\hline Specific gravity & 200000 \\
\hline
\end{tabular}




\subsubsection{Aggregates}

Natural sand with fineness modulus of 2.32 and specific gravity of 2.65 was used as fine aggregate. Crushed dolomite stone with nominal maximum size of $28 \mathrm{~mm}$ and specific gravity of 2.70 was used as coarse aggregate.

Sieve analysis test were carried out on the used Aggregates and results are listed in Table (6) and Table (7)

Table 6. Sieve analysis test results of sand

\begin{tabular}{|c|c|c|}
\hline \multirow{2}{*}{$\begin{array}{c}\text { Sieve Size } \\
(\mathbf{m m})\end{array}$} & $\%$ & $\%$ \\
\cline { 2 - 3 } & passing & retained \\
\cline { 2 - 3 } & 100 & 0 \\
\hline 9.5 & 98.6 & 1.4 \\
\hline 4.75 & 96.52 & 3.48 \\
\hline 2.36 & 90.72 & 9.28 \\
\hline 1.18 & 69.82 & 30.18 \\
\hline 0.6 & 12.42 & 87.58 \\
\hline 0.3 & 0 & 100 \\
\hline 0.177 & & \multicolumn{2}{|c|}{ Fine aggregate } \\
\hline
\end{tabular}

$\mathrm{FM}=2.32$

Table 7. Sieve analysis test results of gravel

\begin{tabular}{|c|c|c|}
\hline \multirow{2}{*}{$\begin{array}{c}\text { Sieve Size } \\
\mathbf{m m}\end{array}$} & \multicolumn{2}{|c|}{ coarse aggregate } \\
\cline { 2 - 3 } & passing & \% \\
\cline { 2 - 3 } & 100 & retained \\
\hline 38.1 & 95.57 & 4.43 \\
\hline 28 & 48.83 & 51.17 \\
\hline 19 & 13.43 & 86.57 \\
\hline 14 & 1.13 & 98.87 \\
\hline 9.5 & 0.13 & 99.87 \\
\hline 4.75 & 0.03 & 99.97 \\
\hline 2.36 & 0 & 100 \\
\hline 1.18 & 0 & 100 \\
\hline 0.6 & 0 & 100 \\
\hline 0.3 & 0 & 100 \\
\hline 0.177 & & \\
\hline
\end{tabular}




\subsubsection{Water}

Clean drinking fresh water, free from impurities was used in the mixes. Water-cement ratio was 0.40 by weight.

\subsection{Concrete mixtures}

OPC was partially replaced by silica fume (SF) at $5 \%, 10 \%, 15 \%$ where as fly ash (FA) and super pozz (SP) replaced OPC at $10 \%, 20 \%$ and $30 \%$, by weight of binder. The binder content of concrete was set as a constant of $400 \mathrm{~kg} / \mathrm{m}^{3}$ and mix proportions of concrete are presented in Tables (8, 9, and 10). The amounts of water and coarse aggregate in all concrete mixtures were constant.

Table (8) Mixture proportions for fly ash mixes

\begin{tabular}{|c|c|c|c|c|}
\hline \multirow{2}{*}{ Materials $\left(\mathbf{K g} / \mathbf{m}^{\mathbf{3}}\right)$} & \multicolumn{4}{|c|}{ Mixture Designation } \\
\cline { 2 - 5 } & $\mathbf{1 0 0} \%$ OPC & $\mathbf{1 0} \%$ FA & $\mathbf{2 0} \%$ FA & $\mathbf{3 0} \%$ FA \\
\hline Ordinary Portland cement & 400 & 360 & 320 & 280 \\
\hline Coarse Aggregate & 1212.34 & 1212.34 & 1212.34 & 1212.34 \\
\hline Fine Aggregate & 681.94 & 675.6 & 669.3 & 662.9 \\
\hline Water & 160 & 160 & 160 & 160 \\
\hline HRWR (L/m3) & 8 & 8 & 8 & 8 \\
\hline Fly Ash & - & 40 & 80 & 120 \\
\hline Calculated Unit Wt & 2462 & 2456 & 2450 & 2443 \\
\hline w/c & 0.4 & 0.4 & 0.4 & 0.4 \\
\hline
\end{tabular}

Table (9) Mixture proportions for super pozz mixes

\begin{tabular}{|c|c|c|c|c|}
\hline \multirow{2}{*}{ Materials $\left(\mathbf{K g} / \mathbf{m}^{\mathbf{3}}\right)$} & \multicolumn{4}{|c|}{ Mixture Designation } \\
\cline { 2 - 5 } & $\mathbf{1 0 0} \%$ OPC & $\mathbf{1 0} \%$ SP & $\mathbf{2 0} \%$ SP & $\mathbf{3 0 \% ~ S P ~}$ \\
\hline Ordinary Portland cement & 400 & 360 & 320 & $\mathbf{2 8 0}$ \\
\hline Coarse Aggregate & 1212.34 & 1212.34 & 1212.34 & 1212.34 \\
\hline Fine Aggregate & 681.94 & 673.7 & 665.5 & 657.2 \\
\hline Water & 160 & 160 & 160 & 160 \\
\hline HRWR (L/m3) & 8 & 8 & 8 & 8 \\
\hline Super-Pozz & - & 40 & 80 & 120 \\
\hline Calculated Unit Wt & 2462 & 2454 & 2445 & 2437 \\
\hline w/c & 0.4 & 0.4 & 0.4 & 0.4 \\
\hline
\end{tabular}


Table (10) Mixture proportions for silica fume mixes

\begin{tabular}{|c|c|c|c|c|}
\hline \multirow{2}{*}{ Materials $\left(\mathbf{K g} / \mathbf{m}^{\mathbf{3}}\right)$} & \multicolumn{4}{|c|}{ Mixture Designation } \\
\cline { 2 - 5 } & $\mathbf{1 0 0} \% \mathbf{H S C}$ & $\mathbf{5 \%} \mathbf{~ S F}$ & $\mathbf{1 0} \% \mathbf{~ S F}$ & $\mathbf{1 5} \% \mathbf{~ S F}$ \\
\hline Ordinary Portland cement & 400 & 380 & 360 & 340 \\
\hline Coarse Aggregate & 1204.4 & 1212.34 & 1212.34 & 1212.34 \\
\hline Fine Aggregate & 677.5 & 674.11 & 666.28 & 658.46 \\
\hline Water & 160 & 160 & 160 & 160 \\
\hline HRWR (L/m3) & 8 & 8 & 8 & 8 \\
\hline silica fume & - & 20 & 40 & 60 \\
\hline Calculated Unit Wt & 2450 & 2455 & 2447 & 2439 \\
\hline w/c & 0.4 & 0.4 & 0.4 & 0.4 \\
\hline
\end{tabular}

\subsection{Testing}

\subsubsection{Water permeability}

The Permeability of concrete was determined through DIN 1048 (Part 5). permeability test gives a measure of the resistance of concrete against the penetration of water exerting pressure. It shall normally be carried out when the age of the concrete is 28 to 35 days.

A concrete specimen shall be exposed either from above or below to a water pressure of 5 bar acting normal to the mould- filling direction Figures 2, 3. For a period of three days. This pressure shall be kept constant throughout the test. If water penetrates through to the underside of the specimen, the test may be terminated and the specimen rejected as failed. It shall be checked whether and when the unexposed specimen faces show signs of water permeation. Immediately after the pressure has been released, the specimen shall be removed and split down the centre, with the face which was exposed to water facing down. When the split faces show signs of drying (after about 5 to 10 minutes), the maximum depth of penetration in the direction of slab thickness, shall be measured, in $\mathrm{mm}$, and the extent of water permeation established. The mean of the maximum depth of 
penetration obtained from three specimens thus tested shall be taken as the test result.

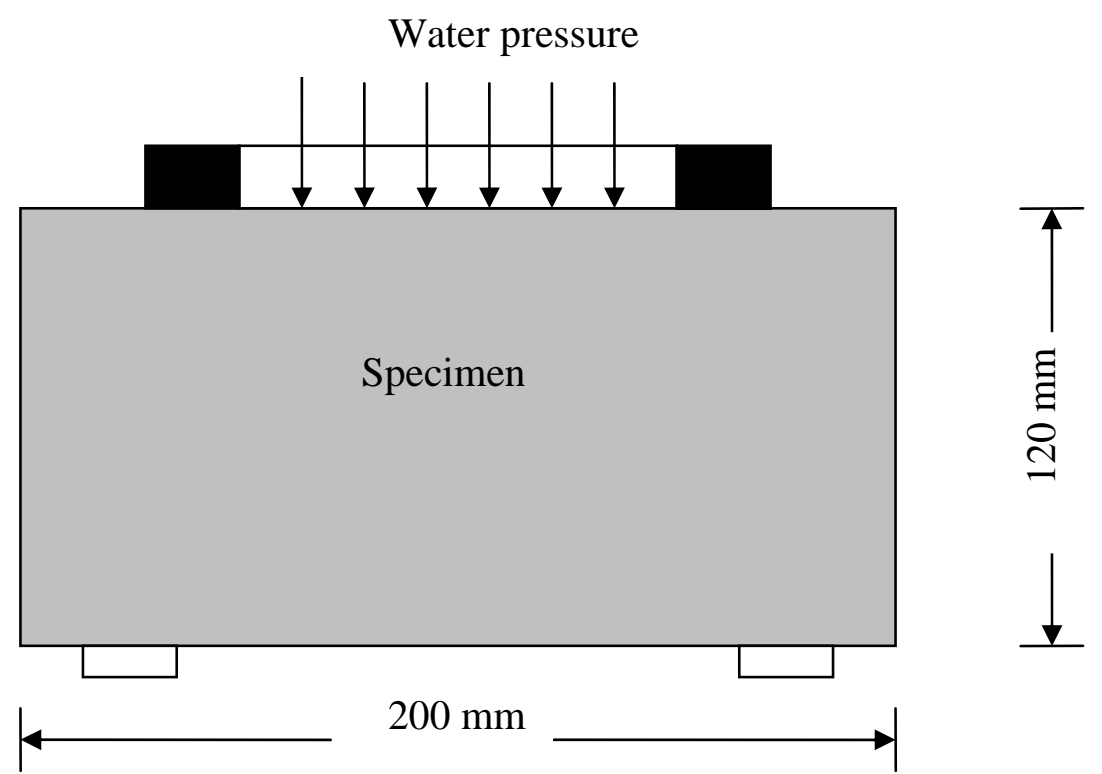

Figure 2: Testing water impermeability on sample $120 \mathrm{~mm} \times 200 \mathrm{~mm} \times 200 \mathrm{~mm}$

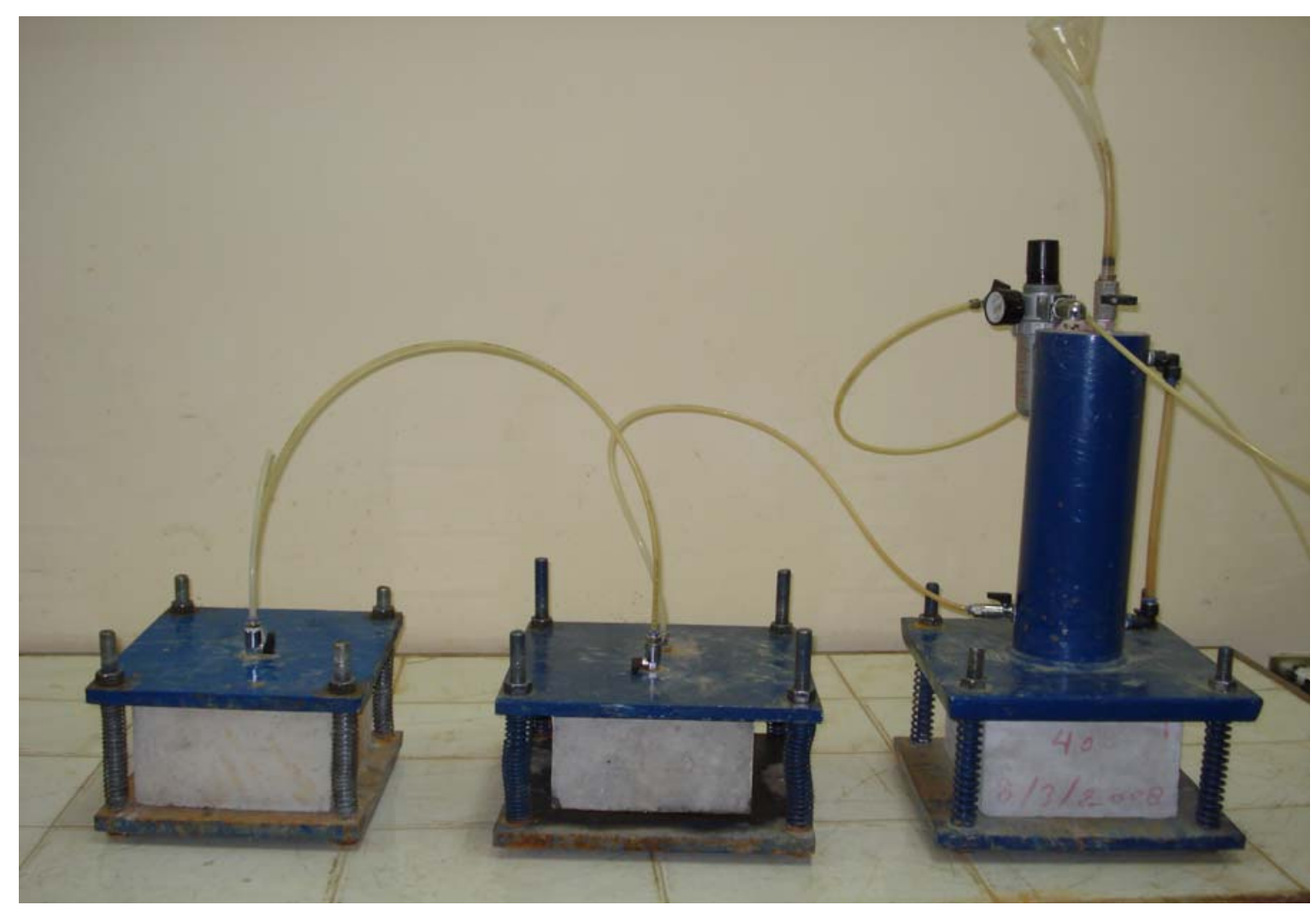

Figure 3: Apparatus of permeability test 


\subsubsection{Compressive strength}

Concretes cubes of $150 \mathrm{~mm}$ were used to determine the compressive strength. The samples were demolded $24 \mathrm{~h}$ after casting and cured in water until the testing ages. The compressive strengths of concretes were determined at the ages of 28 days.

\section{RESULTS AND DISCUSSION}

\subsection{Water permeability of concretes}

The water permeability of concrete and the ratio of permeability are given in Table (11) and Figure 3. The ratio of permeability is defined as the permeability of concrete containing pozzolanic materials divided by the permeability of OPC concrete at the same age of testing. The mean of the maximum depth of water penetration of $20 \%$ FA concrete had lower an average reduction of $44 \%$ compared to the control mixture $\mathrm{OPC}$.

The mixture containing blast furnace slag had an average reduction of $7 \%$ when compared to the control mixture. Mixture $10 \% \mathrm{SF}$ should have a lower value than of the OPC with reduction $66 \%$. The fine particle sizes of the silica fume fills in the spaces between the cement particles and making the concrete much denser than mixtures without silica fume. The mixture containing 10\%SP had lowest water permeability value compared to all mixtures.

\subsection{Compressive strength}

Compressive strengths of concretes are compared to OPC concrete in Table (11) and Figure 4. The compressive strength at 28 days of OPC concrete was 465 $\mathrm{kg} / \mathrm{cm}^{2}$. The concrete containing high slag cement had the compressive strength of $517 \mathrm{~kg} / \mathrm{cm}^{2}$ or $111 \%$ of the OPC. Compressive strengths of $10 \% \mathrm{FA}, 20 \% \mathrm{FA}, 30 \%$ FA concretes were $435,414,370 \mathrm{~kg} / \mathrm{cm}^{2}$ or $94 \%, 89 \%, 80 \%$ of the OPC concrete, respectively. At higher replacement ratio ( $30 \% \mathrm{FA})$, the strength of concrete lowest since the amount of Portland cement was greatly reduced. For series of SP concretes the compressive strengths were 486,422 , and $386 \mathrm{~kg} / \mathrm{cm}^{2}$ or $105 \%, 91 \%$ and $83 \%$ of the OPC concrete, for $10 \%$ SP, $20 \%$ SP and $30 \%$ SP concretes, respectively. Again, increasing in replacement ratio of $\mathrm{SP}$, the compressive strength of concrete was reduced, but was still slightly higher than that of FA concretes. For series of SF concretes the compressive strengths were 504,643 , and $533 \mathrm{~kg} / \mathrm{cm}^{2}$ or $108 \%, 133 \%$ and $115 \%$ of the OPC concrete, for $5 \%$ SF, $10 \%$ SF and $\% 15$ SF concretes, respectively. \%10 SF had higher compressive strengths because Silica fume is much finer than the Super-Pozz. As a result of the higher surface area the pozzolanic reaction proceeds rapidly and strength is quickly developed . 
Table (11) Results of Compressive strength and max penetration water depth

\begin{tabular}{|c|c|c|c|c|}
\hline \multirow{2}{*}{ Mixed } & \multicolumn{2}{|c|}{$\begin{array}{c}\text { Compressive strength 28 } \\
\text { days }\end{array}$} & \multicolumn{2}{c|}{$\begin{array}{c}\text { Max penetration water } \\
\text { depth }\end{array}$} \\
\cline { 3 - 5 } & value(kg/cm ${ }^{2}$ ) & $\begin{array}{c}\text { \% of } \\
\text { control mix }\end{array}$ & Value (mm) & $\begin{array}{c}\text { \% of } \\
\text { control mix }\end{array}$ \\
\hline OPC (control mix) & $\mathbf{4 6 5}$ & $\mathbf{1 0 0}$ & $\mathbf{2 7}$ & $\mathbf{1 0 0}$ \\
\hline HSC & 517 & 111 & 25 & 93 \\
\hline $10 \mathrm{FA}$ & 435 & 94 & 23 & 85 \\
\hline $20 \% \mathrm{FA}$ & 414 & 89 & 15 & 56 \\
\hline $30 \% \mathrm{FA}$ & 370 & 80 & 28 & 104 \\
\hline $10 \% \mathrm{SP}$ & 486 & 105 & 10 & 37 \\
\hline $20 \% \mathrm{SP}$ & 422 & 91 & 22 & 82 \\
\hline $30 \% \mathrm{SP}$ & 386 & 83 & 30 & 111 \\
\hline $5 \% \mathrm{SF}$ & 504 & 108 & 20 & 74 \\
\hline $10 \% \mathrm{SF}$ & 643 & 138 & 12 & 44 \\
\hline $15 \% \mathrm{SF}$ & 533 & 115 & 16 & 59 \\
\hline
\end{tabular}

\section{CONCLUSIONS}

1. The optimum cement replacement by $\mathrm{FA}, \mathrm{SP}$ and $\mathrm{SF}$ in this experiment is $10 \%$ SP.The higher replacement than this ratio results in the higher of permeability concrete and tends to give lower compressive strength.

2. SF concretes have higher compressive strength at all cement replacement levels Strength and tends to give lower permeability of concrete.

3. The permeability of SP, FA and SF concretes depends on the cement replacement ratios. In general, the permeability of concrete reduces with the increasing in the compressive strength and age of concrete. 


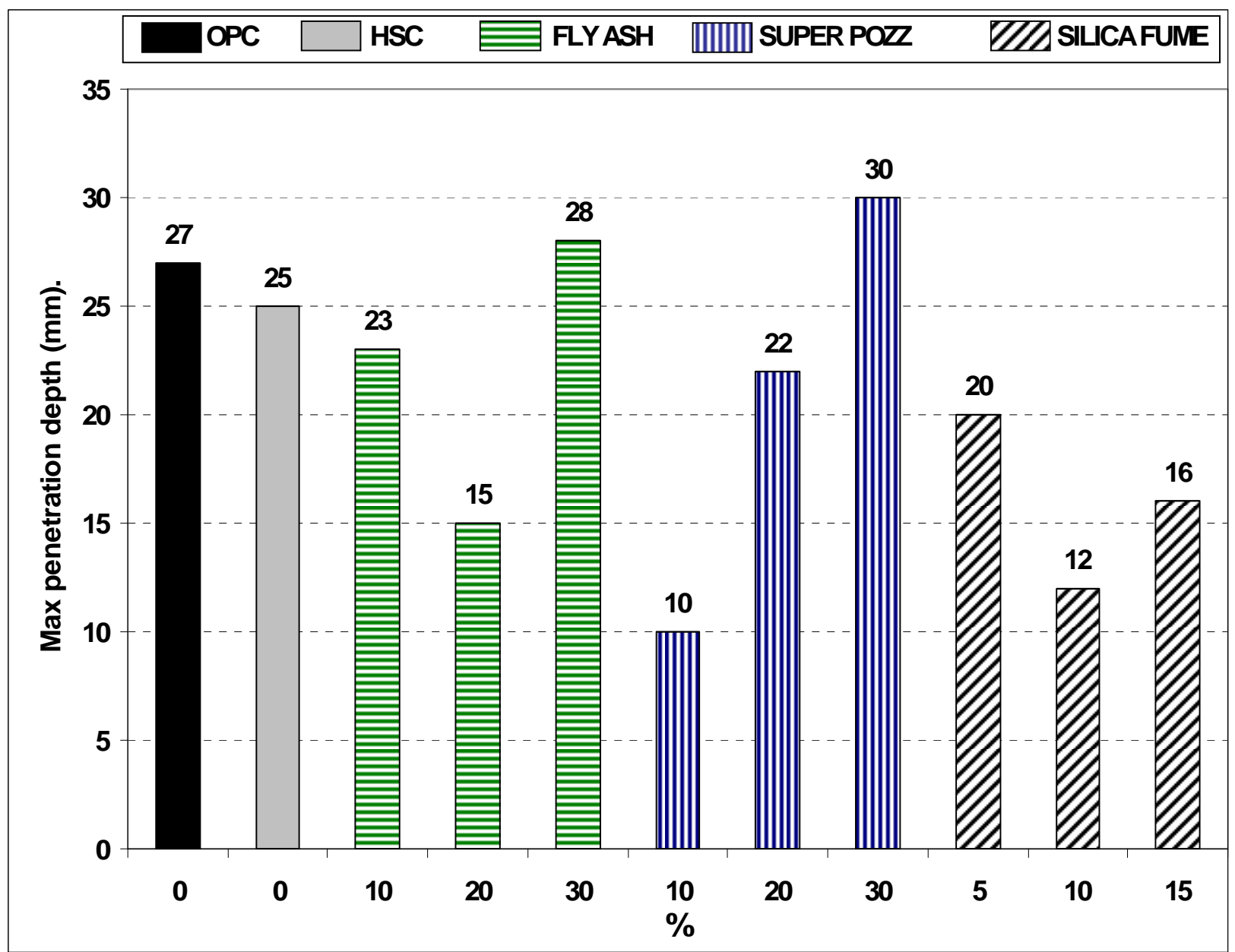

Figure 3: Results of maximum water penetration depth $(\mathrm{mm})$ 


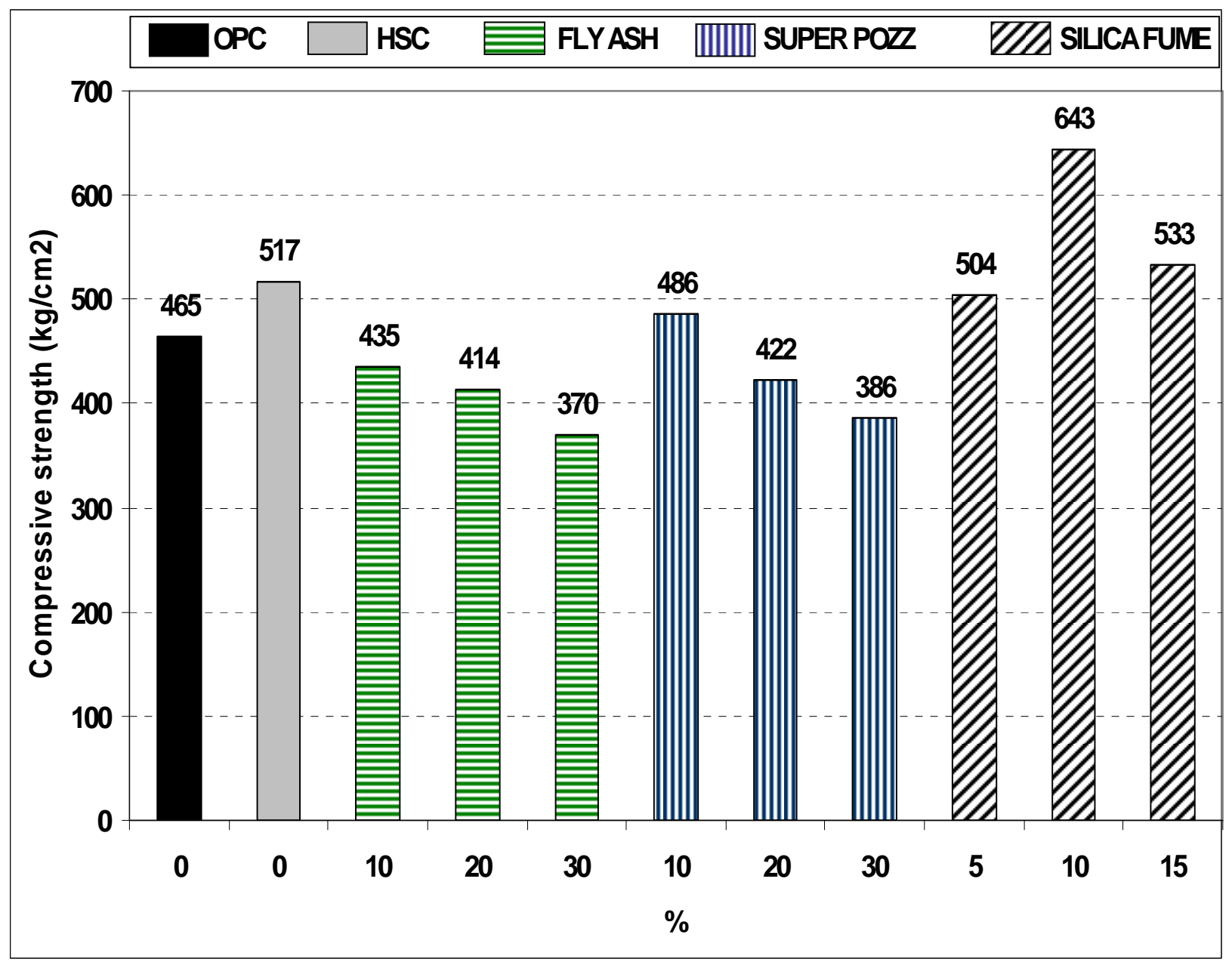

Figure 4: Results of Compressive strength $\left(\mathrm{kg} / \mathrm{cm}^{2}\right)$ 


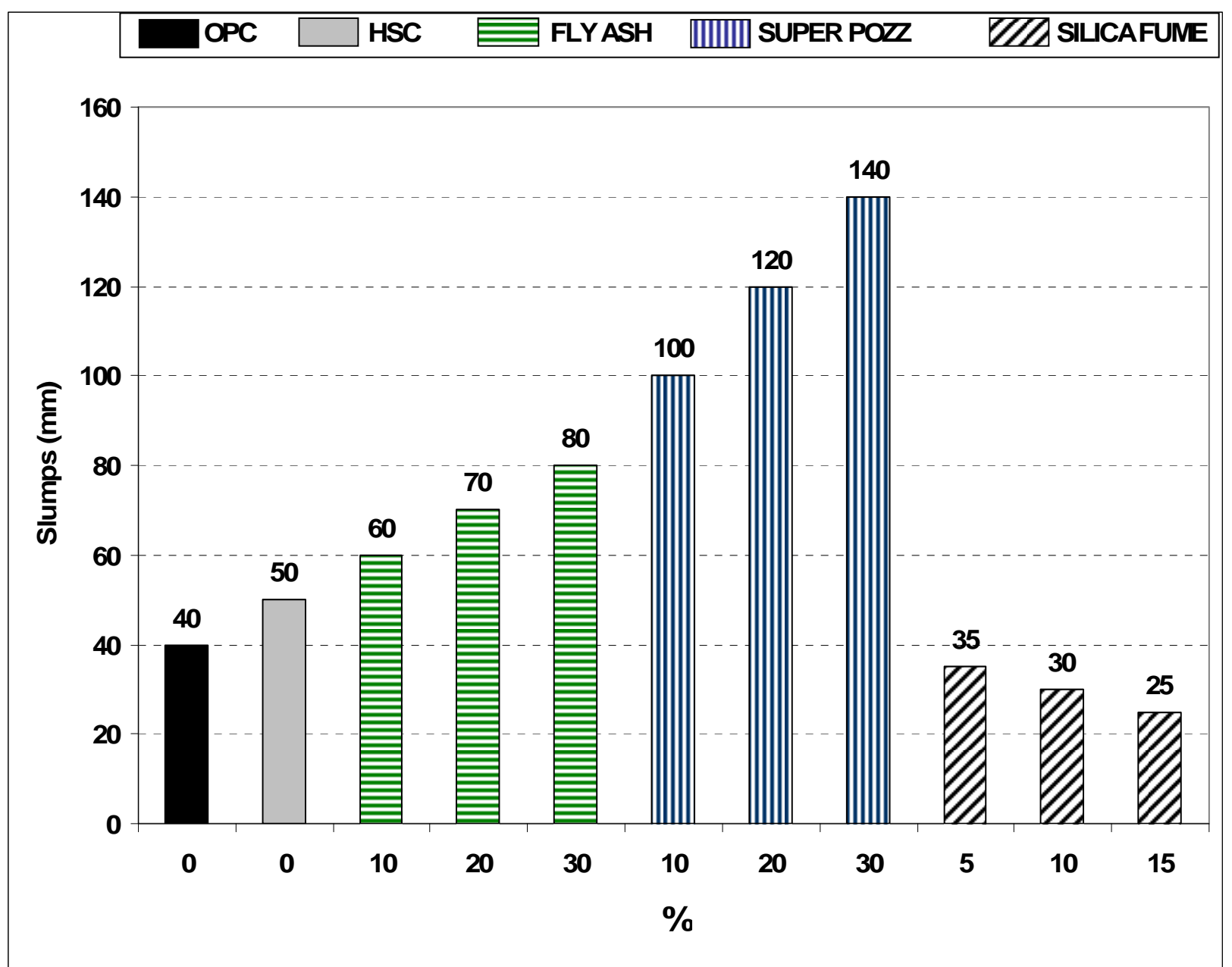

Figure 5: Results of slumps (mm) 


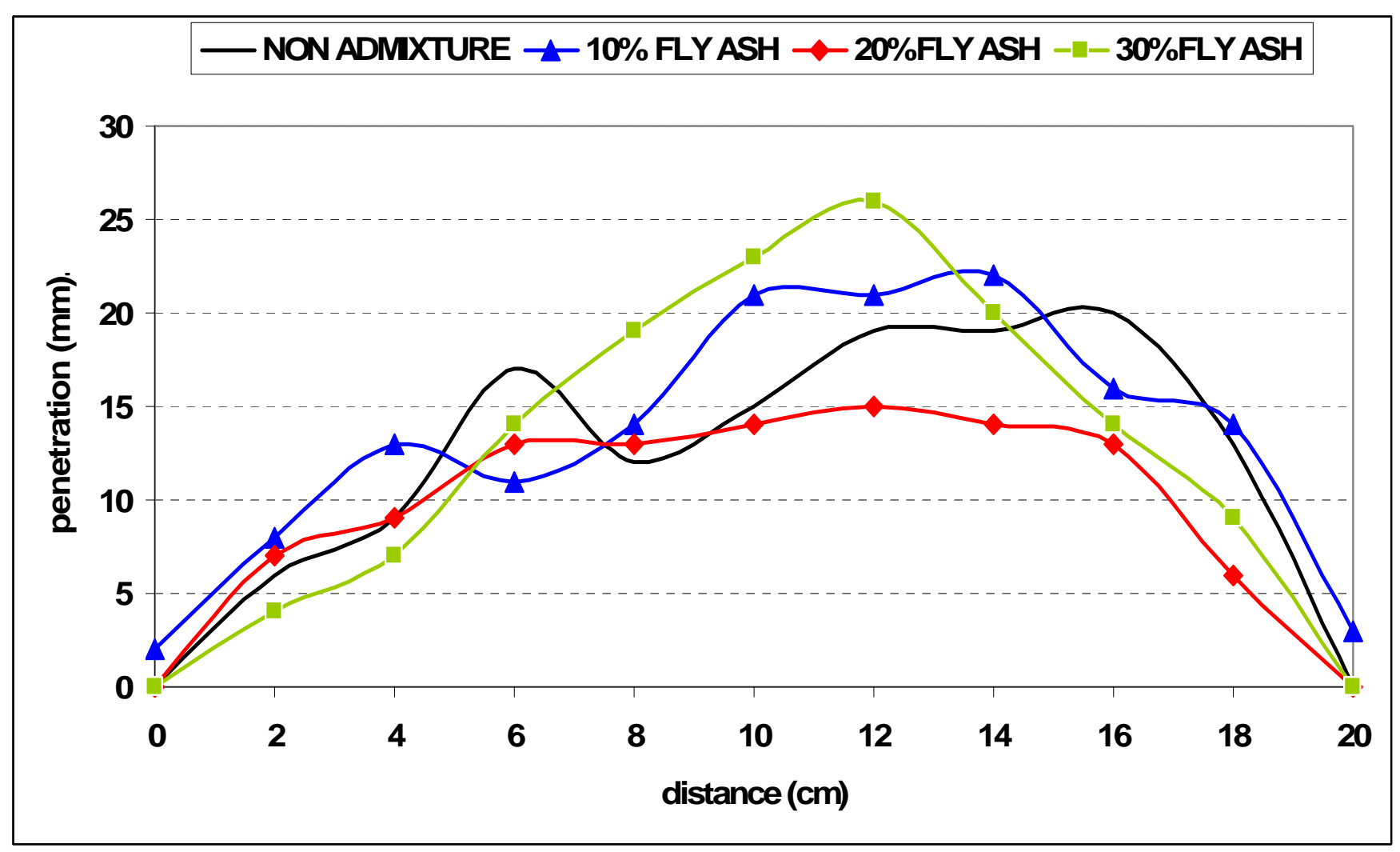

Figure (6) Average water penetration curves with different FLY ASH ratios.

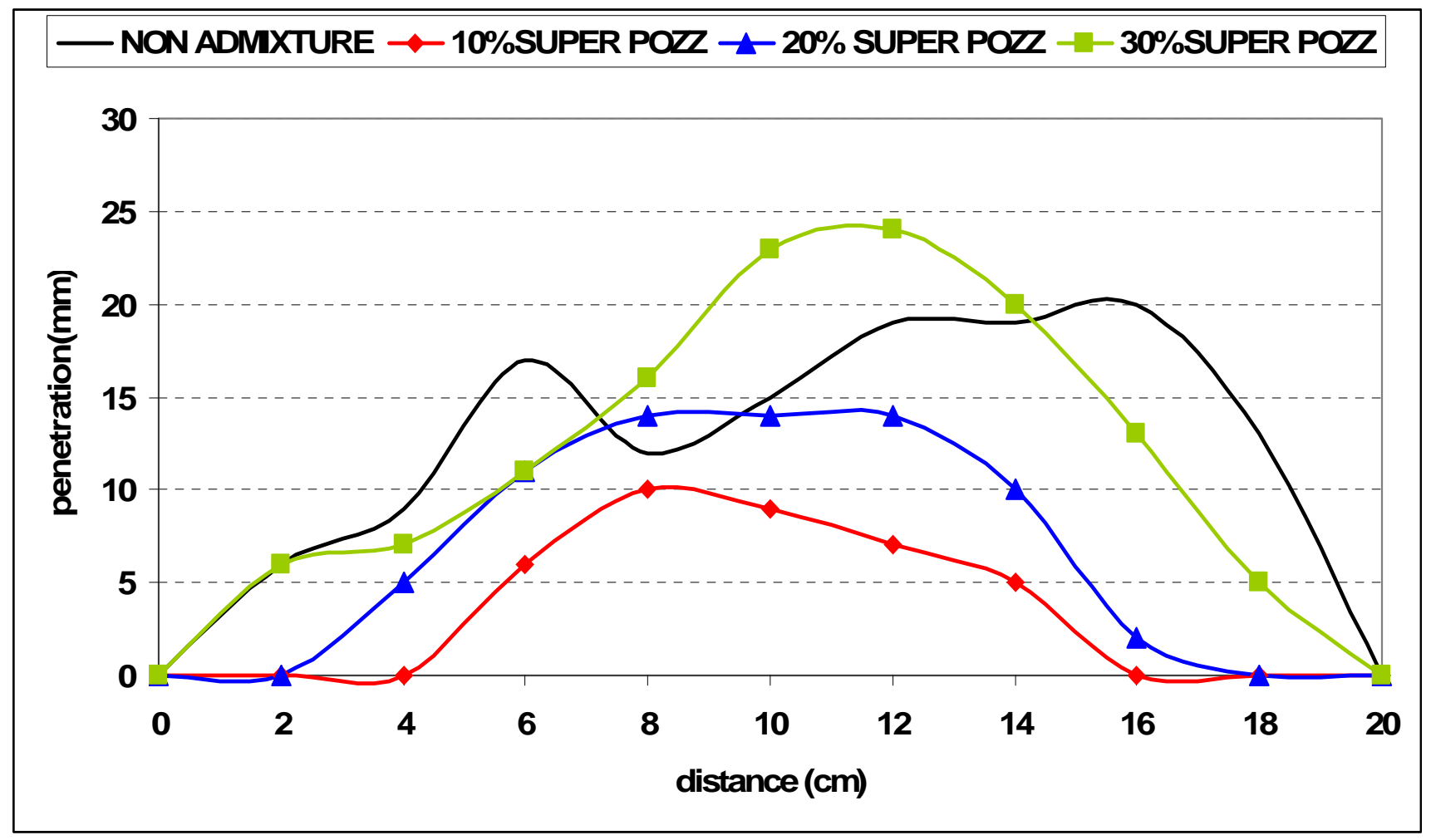

Figure (7) Average water penetration curves with different SUPER POZZ ratios. 


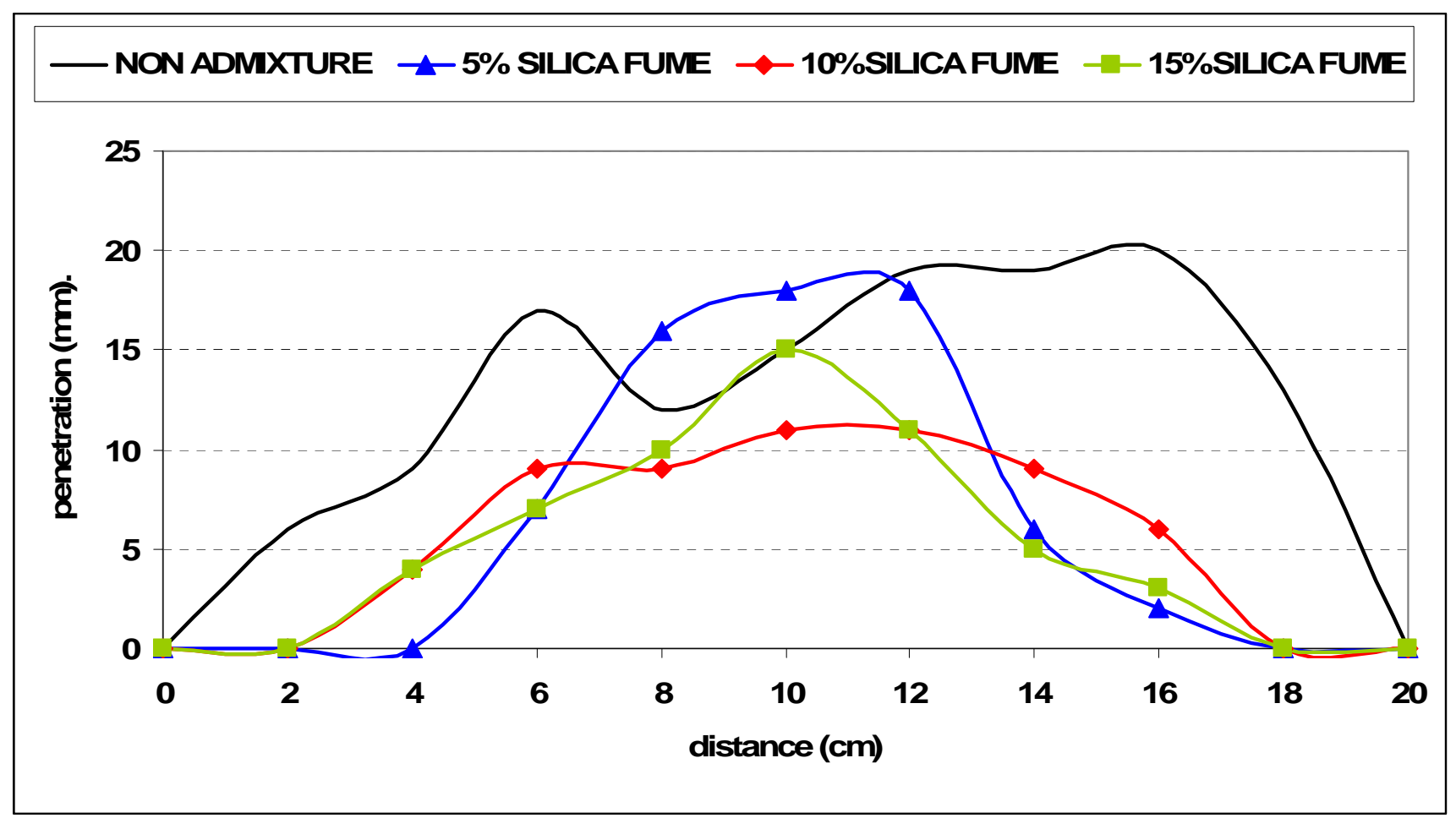

Figure (8) Average water penetration curves with different SILICA FUME ratios.

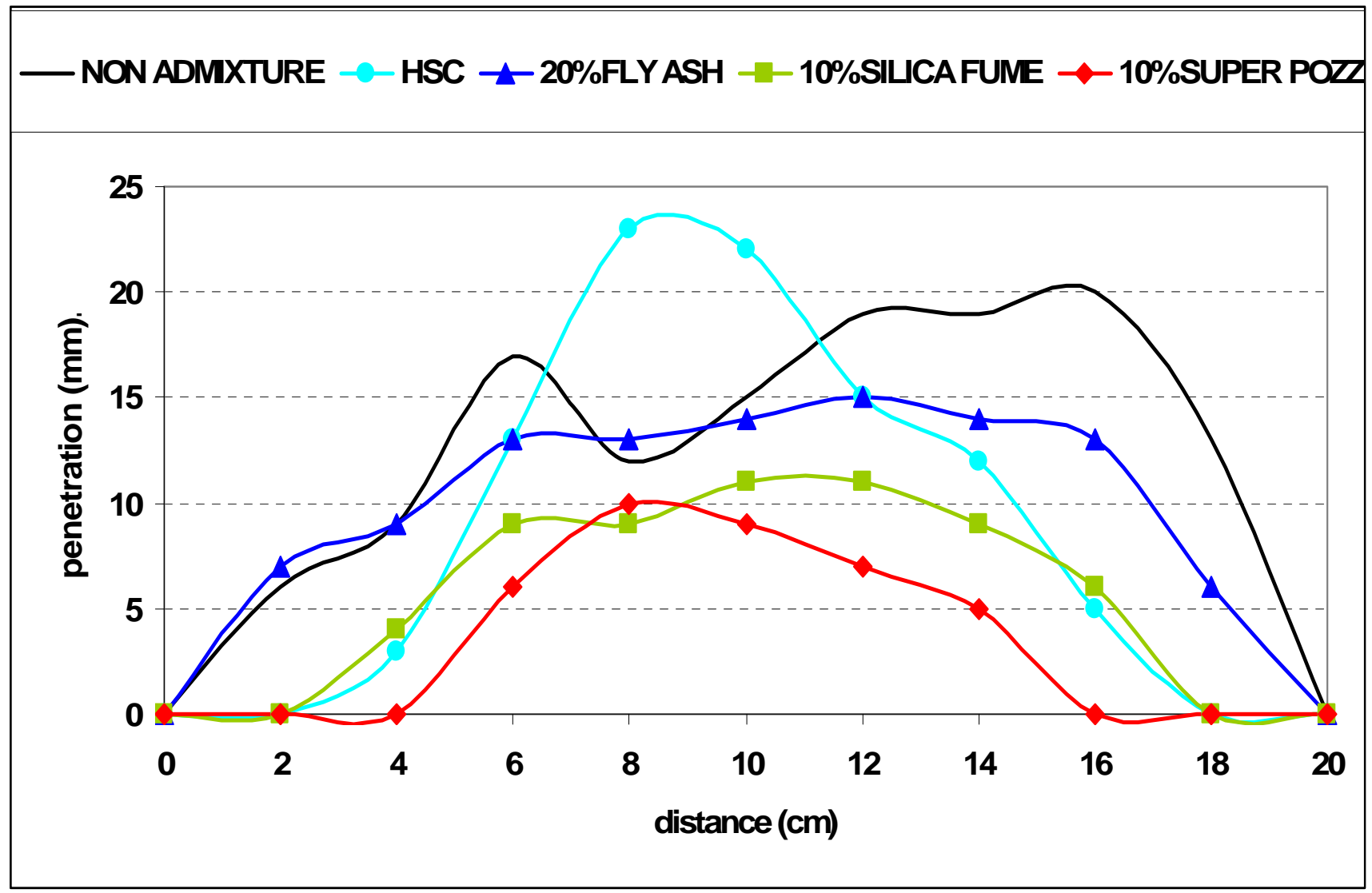

Figure (9) Comparison of the average water penetration curves with the best ratios of different admixture. 


\section{REFERENCES}

[1] Marsh BK, Day RL, Bonner DG. Pore structure characteristics affecting the permeability of cement paste containing fly ash. Cement Concrete Res 1985; 15(6):1027-38.

[2] Alexander MG, Magee BJ. Durability performance of concrete containing condensed silica fume. Cement Concrete Res 1999; 29(6):917-22.

[3] Mehta, P. Kumar, "Concrete Structure, Properties, and Materials", Prentice- Hall, Inc., Englewood Cliffs, N.J. 07632, 1993.

[4] Klieger, Paul, Joseph F. Lamond (Eds.), Significance of Tests and Properties of Concrete and Concrete-Making Materials, ASTM STP 169C, 1994.

[5] Konstantin G. Sobolev and Vladimir G. Batrakov Journal of Materials in Civil Engineering ( ) ASCE / October 2007 / 812 [6] Mindess. Sidney, Young. J. Francis. Concrete. P 24. Prentice- Hall, Inc., Englewood Cliffs, New Jersey 07632

[7] Helmuth, R. A., Fly Ash in Cement and Concrete, SP040T, Portland Cement Association, Skokie, IL, 1987.

[8] ASTM C 618. American Society for Testing and Materials. ASTM Specification for Fly Ash and Raw or Calcined Natural Pozzolan for use as a Mineral Admixture in Portland Cement Concrete. Designation C 618.

Philadelphia: American Society for Testing and Materials.

[9] Lewis, D. W., Discussion of "Admixtures for Concrete," (ACl 212.1R-81), Concrete International: Design and Construction, Vol. 27, No. 5, May 1985, pp. 64-65.

[10] Fulton, F. S., the Properties of Portland Cements Containing Milled Granulated Blast-furnace Slag, Portland Cement Institute Monograph, The Portland Cement Institute, Johannesburg, South Africa, 1974. 